\title{
Temporal and spatial distributions of delphinid species in Massachusetts Bay (USA) using passive acoustics from ocean gliders
}

\author{
Tammy L. Silva ${ }^{1,2,3,4, *}$, T. Aran Mooney ${ }^{2}$, Laela S. Sayigh ${ }^{2}$, Mark F. Baumgartner ${ }^{2}$ \\ ${ }^{1}$ Department of Biology, University of Massachusetts Dartmouth, N. Dartmouth, Massachusetts 02747, USA \\ ${ }^{2}$ Biology Department, Woods Hole Oceanographic Institution, Woods Hole, Massachusetts 02543, USA \\ ${ }^{3}$ Present address: School for Marine Science and Technology, University of Massachusetts Dartmouth, New Bedford, \\ Massachusetts 02744, USA
}

${ }^{4}$ Present address: Stellwagen Bank National Marine Sanctuary, National Oceanic and Atmospheric Administration, Scituate, Massachusetts 02066, USA

\begin{abstract}
Knowledge about marine mammal habitat use is necessary for informing ecosystem-based management and mitigating human impacts. Massachusetts Bay is an important marine mammal foraging area in the Gulf of Maine and an area of substantial human activity, but delphinid habitat use is poorly understood. The goals of this work were to (1) document temporal and spatial occurrence of delphinid species in Massachusetts Bay using passive acoustic monitoring from ocean gliders and (2) explore the potential influences of environmental conditions on delphinid distributions. Gliders were deployed in late fall and early winter of 2014 and 2015-2016 and were equipped with a digital acoustic recorder and conductivitytemperature-depth instrument. Gliders surveyed an area of approximately $1000 \mathrm{~km}^{2}$. Delphinid whistles were detected on 93 of 128 (73\%) deployment days. Animals were detected more often at night. Presence was consistent over 2 years, although detection rates showed annual and monthly variability. Spatial distribution differed between years, but most detections occurred close to Stellwagen Bank. Visual assessment of spectrograms suggests the presence of 2 species, Atlantic white-sided dolphins and common dolphins. The reoccurrence of 2 probable signature whistles over several weeks and consecutive winter seasons suggests prolonged occupancy during winter and possible annual site fidelity. These data show a consistent and frequent presence of delphinids near a known marine mammal foraging area (Stellwagen Bank) during late fall and winter and are a first step towards understanding both how odontocetes influence the Massachusetts Bay/Gulf of Maine ecosystem and how they may be impacted by human activities.
\end{abstract}

${ }^{*}$ Corresponding author: tsilva4@umassd.edu

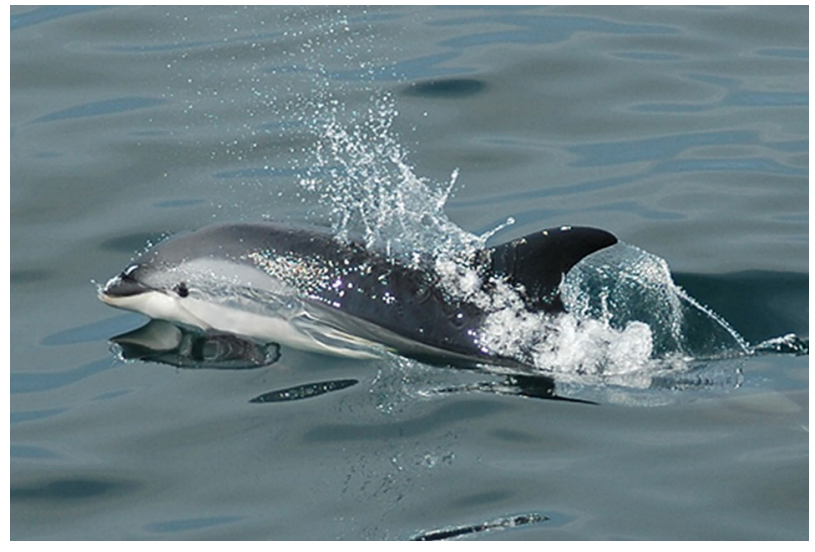

An Atlantic white-sided dolphin, which may be an important Gulf of Maine visitor.

Photo: Tammy Silva

KEY WORDS: Odontocetes - Habitat use - Passive acoustic monitoring · Stellwagen Bank · Gulf of Maine · Slocum gliders

\section{INTRODUCTION}

Basic information on the occurrence and distributions of marine mammal species is essential for understanding and managing ecosystems. Marine mammals structure ecosystems through trophic dynamics (top-down control), nutrient recycling and transportation, or behavioral processes such as migration, predator avoidance, or mediation of interactions between species (Bowen 1997, Williams et al. 2004,

(C) The authors 2019. Open Access under Creative Commons by Attribution Licence. Use, distribution and reproduction are unrestricted. Authors and original publication must be credited. 
MacLeod et al. 2007, Roman \& McCarthy 2010, Kiszka et al. 2015, Breed et al. 2017). One example of the ecological influence of marine mammals is the cascade in the North Pacific Ocean, whereby killer whale predation on sea otters leads to release of predation on kelp-consuming sea urchins by otters, resulting in collapse of kelp forest ecosystems (Estes et al. 1998, 2016).

Data on spatial and temporal occurrence of marine species are also required for assessment and mitigation of human impacts (Asaro 2012, Wiley et al. 2013). Anthropogenic threats to marine mammals include ship strikes, pollution, entanglement in fishing gear, and exposure to ocean noise (Read et al. 2006, Hatch et al. 2008, 2012, van der Hoop et al. 2013, Kellar et al. 2017). While habitat use data, including environmental drivers of distributions, are fundamental for understanding human impacts and marine mammal ecology, we often lack such data.

Traditional visual surveys are useful for gathering basic information such as identification of species, estimates of group size and composition, and abundance (Cetacean and Turtle Assessment Program 1982, Bradford et al. 2017); however, using visual methods to elucidate marine mammal habitat use can be challenging. Many species are highly mobile, have large home ranges (Wells et al. 1999, Thorne et al. 2017), and exhibit cryptic behavior (Tyack et al. 2006), all of which can make vessel or aerial surveys costly or impractical. Passive acoustic monitoring is an established method for studying marine mammal occurrence that offers several advantages over visual methods, including reduced cost and the ability to survey at night or in inclement weather. Further, passive acoustic data collection can occur at a variety of temporal (minutes to years) and spatial (meters to thousands of kilometers) scales to address a range of habitat use questions (Mellinger et al. 2007, Van Parijs et al. 2009).

Recently, passive acoustic monitoring of marine mammal populations has been accomplished using long-endurance, autonomous underwater gliders (Baumgartner \& Fratantoni 2008, Klinck et al. 2012, Baumgartner et al. 2013, 2014). These mobile, relatively inexpensive platforms can remain at sea for days to months and survey hundreds to thousands of kilometers during a single deployment, providing an advantage over fixed recorders in spatial coverage and ability to document animal distributions over large areas. Gliders are particularly useful tools for surveying areas that are difficult to access due to unfavorable conditions (Baumgartner et al. 2014). An additional advantage of gliders is the ability to effi- ciently characterize marine mammal habitats using oceanographic data collected with onboard sensors (Baumgartner \& Fratantoni 2008, Baumgartner et al. 2014).

Massachusetts Bay is a highly productive ecosystem in the southwestern Gulf of Maine. Near the eastern edge of Massachusetts Bay is Stellwagen Bank, an oval-shaped, underwater plateau that strongly influences local oceanography, leading to elevated productivity and its designation as a national marine sanctuary (Bumpus 1974, Geyer et al. 1992). The Stellwagen Bank area is a critical foraging ground for several baleen whale species (Overholtz \& Nicolas 1979, Jiang et al. 2007), and their occurrence and overlap with human activities has been well documented (Wiley et al. 2003, Hatch et al. 2008, Mussoline et al. 2012). Delphinid species have also been documented in Massachusetts Bay. The Atlantic white-sided dolphin Lagenorhynchus acutus and common dolphin Delphinus delphis are sighted most frequently, but little is known about their occurrence, distribution, or overlap with human activity.

Opportunistic sightings from whale watching vessels indicate that delphinids are seen relatively infrequently in Massachusetts Bay. Sightings occur on roughly $10-20 \%$ of whale watching trips operating daily (weather permitting) from April to October (pers. obs.). Times of peak occurrence may differ between years and between species, but most sightings of Atlantic white-sided dolphins and common dolphins occur in April-May and August-October (Silva 2018, Silva et al. 2019). Anecdotal observations and a study by Weinrich et al. (2001) suggest that delphinid species are transient visitors to Massachusetts Bay, occasionally passing through the area as part of a large, oceanic home range.

Monthly standardized visual surveys conducted from vessels in 1994-1995 and 2001- 2002 showed a year-round delphinid presence in Massachusetts Bay, but with striking seasonality; most sightings occurred from November to April (Wiley et al. 2003, NOAA OMNS 2010). However, although these surveys represent our only systematic information about delphinid occurrence in Massachusetts Bay during winter, they were conducted only once per month in 2 years and are well over a decade old.

Additional evidence suggests that winter could be an important time for delphinids in Massachusetts Bay. Most marine mammal strandings in Massachusetts, including those of delphinids, occur from October to April (Wiley et al. 2001). In addition, Kenney et al. (1997) estimated that the Atlantic white-sided dolphin was the dominant cetacean species in the Gulf 
of Maine during winter. The high trophic status of delphinids in the Gulf of Maine (Kenney et al. 1997, Overholtz \& Link 2007, Craddock et al. 2009), as well as the potential for overlap with year-round human activity in Massachusetts Bay (Wiley et al. 2003, Hatch et al. 2008) warrants investigation into basic patterns of delphinid habitat use.

In 2013, a multi-year effort began to study the winter distribution of spawning Atlantic cod in western Massachusetts Bay using passive acoustics from ocean gliders (Zemeckis et al. 2019), which provided an opportunity to concurrently monitor odontocete occurrence using passive acoustics. This work aimed to increase our understanding of delphinid habitat use in Massachusetts Bay during late fall and early winter. Our goals were to quantify spatial and temporal occurrence of delphinids and explore potential environmental factors influencing their distribution to begin filling a knowledge gap in the ecology of Massachusetts Bay.

\section{MATERIALS AND METHODS}

\subsection{Glider deployments}

Glider deployments were planned as part of a multi-institutional effort to study the distribution of spawning Atlantic cod in Stellwagen Basin, an area of deep water in western Massachusetts Bay (Fig. 1). Glider surveys were planned to cover approximately $1000 \mathrm{~km}^{2}$. Depth across the study area ranged from approximately 30 to $100 \mathrm{~m}$. Little survey effort, visual or acoustic, has been expended during winter in Stellwagen Basin. Therefore, we considered this work largely exploratory.

Gliders operated in Stellwagen Basin during December 2014, and again during the period from early
November 2015 to February 2016 (Table 1). Passive acoustic monitoring was accomplished with a digital acoustic monitoring instrument (DMON, Woods Hole Oceanographic Institution) mounted over the nose of a Slocum glider (Teledyne Webb Research; Rudnick et al. 2004). Recordings were collected using the DMON's mid-frequency hydrophone (flat frequency response from $100 \mathrm{~Hz}$ to $50 \mathrm{kHz}$ and total design sensitivity of $-167 \mathrm{~dB}$ re $\mathrm{V} / \mu \mathrm{Pa}$ ) with a $25 \%$ duty cycle (1 min recording every $4 \mathrm{~min}$ ), and sampled at $60 \mathrm{kHz}$. This sampling frequency was high enough to capture

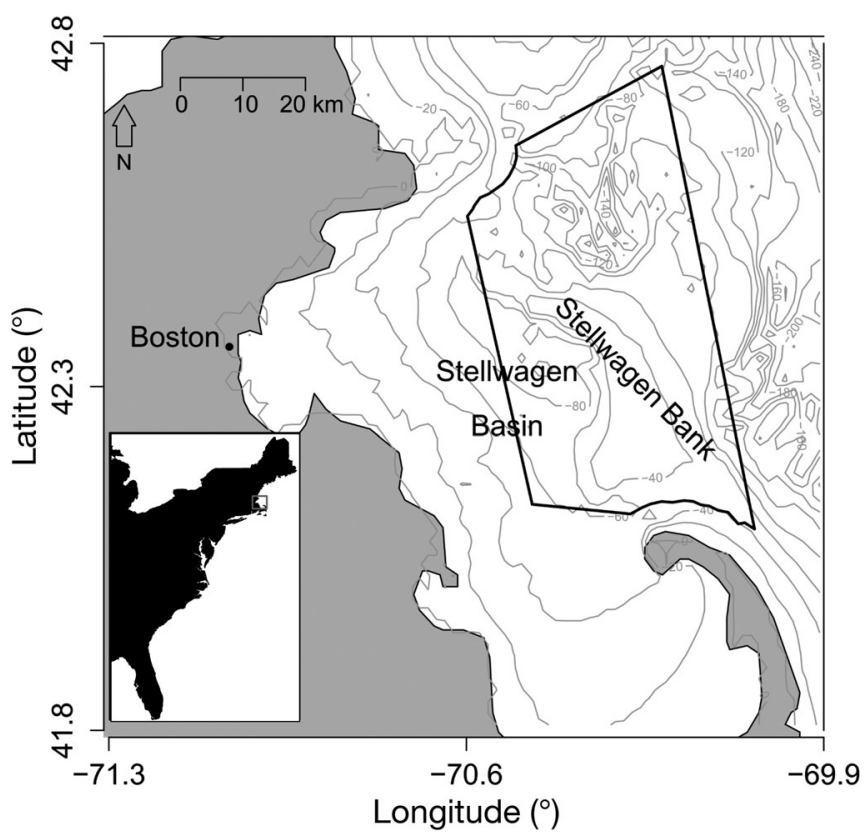

Fig. 1. Study area in Massachusetts Bay. Stellwagen Bank is a productive underwater plateau, encompassed by Stellwagen Bank National Marine Sanctuary (black boundaries). Stellwagen Basin is the deep water to the west of Stellwagen Bank. Bathymetric contours are shown as gray lines with labels. The inset shows the location of the study area in relation to the US east coast

Table 1. Glider deployment details. Total files represents the number of 1 min recording files while the glider was in the water. For quantification of temporal occurrence in 2014, detections from glider we10 were used only from days when no detections occurred on we04 $(2,5$, and 9-10 December, $\mathrm{n}=15)$ to prevent possibly double-counting detections

\begin{tabular}{|c|c|c|c|c|c|c|c|c|}
\hline Year & Glider & Deployed & Recovered & $\begin{array}{l}\text { Total } \\
\text { days }\end{array}$ & $\begin{array}{l}\text { Number of days } \\
\text { whistles present }\end{array}$ & $\begin{array}{c}\text { Days whistles } \\
\text { present }(\%)\end{array}$ & $\begin{array}{l}\text { Total } \\
\text { files }\end{array}$ & $\begin{array}{l}\text { Number of } \\
\text { detections }\end{array}$ \\
\hline \multirow[t]{2}{*}{2014} & we10 & $1 \mathrm{Dec}$ & $22 \mathrm{Dec}$ & $20^{\mathrm{a}}$ & 16 & 80 & 6875 & 406 \\
\hline & we04 & $1 \mathrm{Dec}$ & $22 \mathrm{Dec}$ & 22 & 15 & 68 & 7528 & 513 \\
\hline \multirow[t]{2}{*}{2015} & we04 & $2 \mathrm{Nov}$ & $7 \mathrm{Dec}$ & 36 & 25 & 69 & 12584 & 1218 \\
\hline & we10 & $7 \mathrm{Dec}$ & $21 \mathrm{Jan}$ & $44^{\mathrm{b}}$ & 39 & 95 & 14452 & 2918 \\
\hline 2016 & we03 & 2 Feb & $1 \mathrm{Mar}$ & $29^{b}$ & 9 & 31 & 10063 & 94 \\
\hline
\end{tabular}


most tonal signals produced by delphinid species documented in Massachusetts Bay. A conductivitytemperature-depth (CTD) instrument (Neil Brown Ocean Sensors) was mounted to the glider's midsection to sample conductivity, temperature, and pressure several times per minute. Gliders typically surfaced every $2 \mathrm{~h}$ to report their location, sensor data, and diagnostic information to a shore-based computer via Iridium satellite. Passive acoustic recording continued during this time. Gliders were recovered at pre-determined locations.

\subsection{Acoustic analysis}

Spectrograms (fast Fourier transform, FFT, size 1024 samples, $50 \%$ overlap, Hann window, time resolution: $9 \mathrm{~ms}$, frequency resolution: $58.6 \mathrm{~Hz}$ ) of all $1 \mathrm{~min}$ acoustic recordings were visually and aurally examined for the presence of delphinid whistles using Raven Pro 1.5 beta version build 21 (Charif et al. 2010). We focused on whistles (Oswald et al. 2003, 2007) to increase our chance of documenting delphinid presence throughout the study area. Whistles are produced at lower frequencies than echolocation clicks, have less directionality (Lammers \& Au 2003), and are predicted to be detectable at greater distances (Urick 1983), maximizing the area we could monitor. A detection was defined as the presence of 1 or more whistles in a 1 min recording file. We did not attempt to differentiate between species because there was little existing information on whistle characteristics for delphinid species in the Gulf of Maine, particularly Atlantic white-sided dolphins (Oswald et al. 2003, 2007).

\subsection{Temporal occurrence}

To describe the temporal occurrence of delphinids, we quantified the number of detections per deployment period, per deployment day, and per hour in a $24 \mathrm{~h}$ period. Based on our duty cycle of 1 min every $4 \mathrm{~min}$, the maximum number of detections per hour and per day was 15 and 360, respectively.

We used logistic regression to test for diel differences in detections. For each $24 \mathrm{~h}$ deployment period, daytime and nighttime periods were assigned a ' 1 ' if detections were present and $a$ ' 0 ' if no detections were present. Daily sunrise and sunset times were obtained from the United States Naval Observatory Astronomical Applications Department.

We also investigated the effects of lunar and tidal phases on detections. Because animals were present (detected) during all phases of lunar and tidal cycles, it made more sense to analyze detection rate, while recognizing that interpretation of detection rate is different from presence/absence. For each deployment day, we quantified the mean number of detections (number of 1 min recordings containing whistles) per hour and assigned 1 of 4 main lunar phases: new moon, first quarter, full moon, and last quarter. Only days with detections were used for these analyses. Lunar phase data were also obtained from the United States Naval Observatory Astronomical Applications Department (http://aa.usno.navy.mil). A Kruskal-Wallis test was used to assess differences in detection rates based on phases of the moon.

We obtained tidal cycle data from NOAA (http:// tidesandcurrents.noaa.gov) and divided the cycle into 4 periods: high, ebb, low, and flood. High and low tide were defined as the hour of high or low tide plus $1 \mathrm{~h}$ before and $1 \mathrm{~h}$ after. Flood was defined as the $3 \mathrm{~h}$ period centered between low and high tide. Ebb was defined as the $3 \mathrm{~h}$ period centered between high and low tide. Detection rates (detections $\mathrm{h}^{-1}$ ) were calculated for each tidal phase for each day, and a Kruskal-Wallis test was used to assess the effects of tidal phases on detection rate. Massachusetts Bay experiences a semi-diurnal tide, but no attempt was made to distinguish between the first or second tides of each day.

\subsection{Spatial occurrence}

We visualized spatial distributions of odontocete detections by plotting the locations of detections over the glider tracks using the 'maps' package. All statistical analysis packages were used in $\mathrm{R}$ version 3.3.3 (R Core Team 2017). To quantify general spatial distributions, we tallied the number of detections in each quadrat of a 4-quadrat grid placed over all glider tracks and detections. Each quadrat was approximately $447 \mathrm{~km}^{2}$ and was designed to include roughly the same amount of glider track. We also quantified the number of detections that occurred inside and outside Stellwagen Bank National Marine Sanctuary. Time spent inside and outside the sanctuary was much different for some gliders, so we normalized numbers of detections by track length inside and outside the sanctuary boundaries.

When modeling spatial distributions, autocorrelation in the dependent variable (detections) is a concern (Dormann et al. 2007). Presence of spatial autocorrelation leads to non-independence of data, and potentially, biased model parameter estimates and 
increased probability of Type I errors (Legendre 1993). We tested for spatial autocorrelation using correlograms, plots of distance between observations against autocorrelation values (Legendre 1993), using the 'ncf' package (Bjornstad 2016) in R version 3.3.3 (R Core Team 2017). For each glider deployment, we estimated the distance where autocorrelation equals 0 (the $x$-intercept). Glider tracks were binned according to this distance (hereafter referred to as the distance bin) using the geoDist function in the 'oce' package (Kelley \& Richards 2016) for statistical analysis of environmental conditions.

\subsection{Environmental variables}

We tested 4 environmental variables for associations with detections: depth, distance to Stellwagen Bank, temperature and salinity. Gliders continuously profile the water column during deployments, providing in situ measurements of environmental conditions from the surface to the near-bottom. Initial data inspection showed that surface and near-bottom conditions were similar. We chose to use nearbottom environmental data for 2 reasons: (1) bottom environments are more stable because they are often insulated from ephemeral weather events that cause short-term variability in surface water properties (particularly in deep or stratified waters) and (2) if delphinids are using Massachusetts Bay during the winter, they could likely be feeding on demersal fish that overwinter in the Bay (Meynier et al. 2008, Craddock et al. 2009). The bottom of every glider dive and associated temperature and conductivity measurements were found using the 'findPeaks' function in R. Conductivity values were used to calculate salinity using the 'oce' package (Kelley \& Richards 2016). Outliers were identified by examining temperature-salinity plots, and extreme values were removed before data were averaged over the appropriate distance bin defined by autocorrelation analysis.

Bathymetric data (1 $\mathrm{km}$ resolution) were obtained from the NOAA ETOPO1 1 Arc-Minute Global Relief Model through the 'marmap' package (Pante \& Simon-Bouhet 2013). Sea-floor depths at the location of each glider dive were averaged over the appropriate distance bins. Distance of each bin to Stellwagen Bank (40 m depth contour) was assigned based on the mid-point location of that bin using the Midpoint function in the 'geosphere' package and the 'dist2isobath' function in 'marmap' (Pante \& Simon-Bouhet 2013).

\subsection{Statistical analysis}

We used logistic regression to investigate associations between environmental conditions and delphinid presence. The response variable for each bin was coded as a ' 1 ' if 1 or more detections occurred and a ' 0 ' if no detections occurred. Rather than include all environmental variables in a single model, we chose to examine the influence that each variable had on detections in isolation (Baumgartner et al. 2003). This approach provides a clearer understanding of each variable and stronger inferences about variable significance (Baumgartner et al. 2003, Palacios et al. 2013). We ran single-variable models for each glider separately and for all gliders combined. For the combined analysis, we used the smallest bin distance with no significant autocorrelation that was common to all gliders and included glider deployment as a covariate in the model to account for differences between deployments. We used Akaike Information Criterion (AIC) to compare model fit.

Logistic regression assumes a linear relationship between logits, the log-transformed odds of detection probability, and the independent variables. Generalized additive models (GAMs) with binomial distribution were used to check assumptions of linearity. GAMs do not assume an underlying relationship between logits and the variable, and can automatically identify an appropriate transformation of the variable, allowing for more flexibility. GAMs were fit using the 'mgcv' package (Wood 2011).

\section{RESULTS}

\subsection{Glider deployments}

Five gliders were deployed in western Massachusetts Bay for a total of 128 d in 2014, 2015, and 2016 (Table 1). Gliders were deployed near the northwest corner of the sanctuary (Fig. 2) if sea conditions permitted transit ( 3 gliders). Otherwise, gliders were deployed further south near Stellwagen Bank and then traveled north to begin their survey (2 gliders). Deployments ranged from 22-41 d, during which gliders conducted 1 or 2 surveys (Table 1, Fig. 2). Survey track lines were similar across all gliders and covered approximately $1000 \mathrm{~km}^{2}$. Gliders were recovered in southern Massachusetts Bay.

In 2014, gliders we04 and we10 were deployed on 1 December and surveyed the same path $12 \mathrm{~h}$ apart to capture diel acoustic activity of Atlantic cod. On 13 December, glider we10 was mistakenly retrieved by 

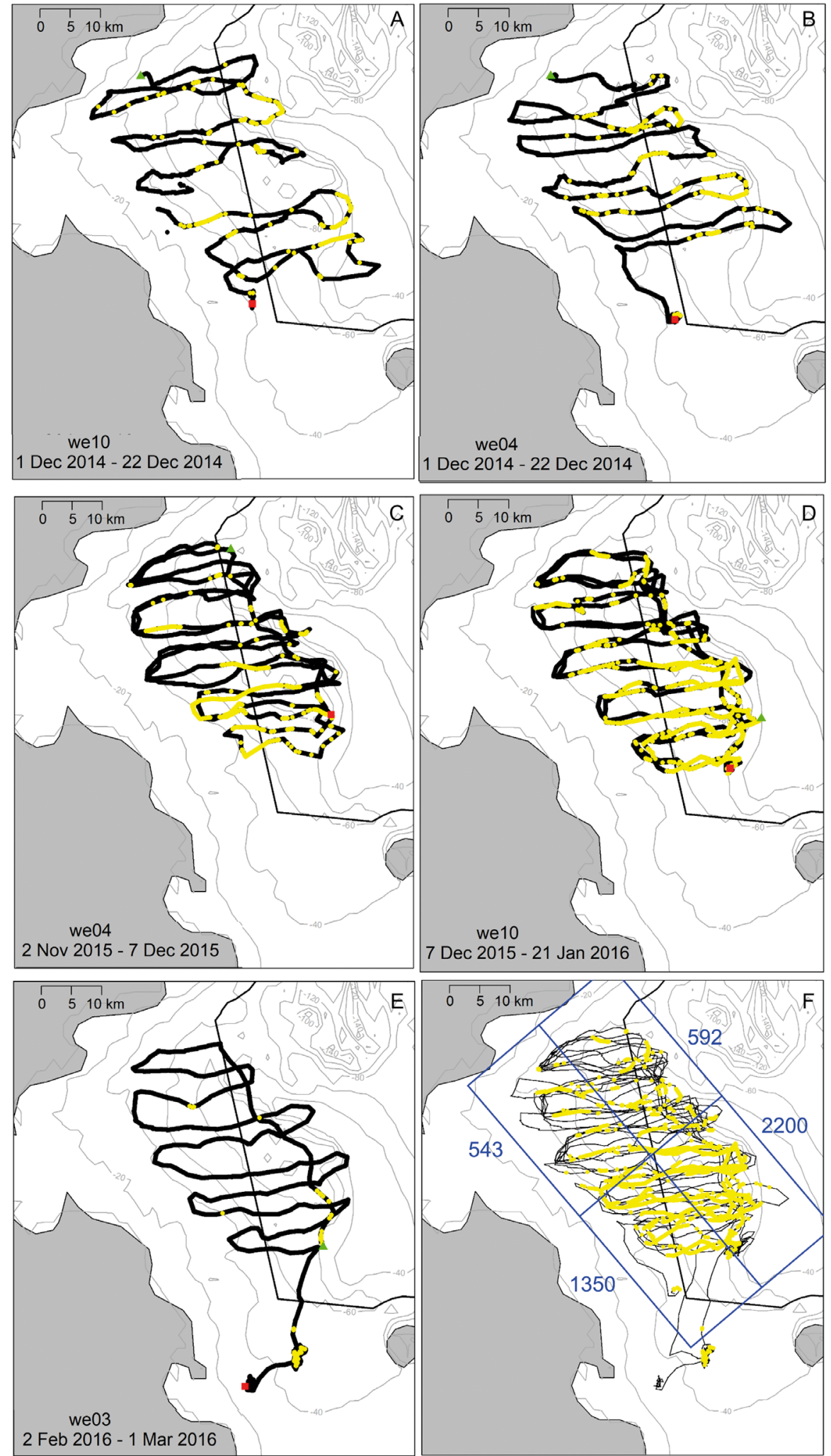

Fig. 2. Glider tracks for all deployments. Green triangles represent glider deployment locations. Red stop signs represent glider recovery locations. Black lines show the glider path. Yellow circles are the locations of the gliders when detections occurred; 2014: (A) we10, (B) we04; 2015-2016: (C) we04, (D) we10, (E) we03. (F) Quadrat counts of detections for all gliders combined (except we10-2014). Values represent the number of detections in each quadrat 
a fisherman. The glider was recovered and redeployed on 15 December; however, the CTD was damaged and collected no additional sensor data. In 2015, glider we04 was deployed on 2 November. Glider we04 was recovered on 7 December, and we10 was deployed on the same day. Glider we10 was recovered on 21 January, but audio memory had filled up on 16 January, resulting in $41 \mathrm{~d}$ of useable data (Table 1). No gliders were in the water between 21 January and 1 February. Glider we03 was deployed on 2 February, 2016. Sensor data were collected until 21 February before the CTD and DMON were powered down to conserve battery until recovery on 1 March.

\subsection{Acoustic recordings}

Recordings contained several sources of gliderrelated noise. Very low frequency flow noise was common $(<20 \mathrm{~Hz}$; measured on the DMON low-frequency hydrophone) due to the location of the DMON on the nose of the glider. This low-frequency noise did not interfere with detecting mid-frequency delphinid whistles. Before and after each glider dive, a displacement piston was activated to adjust the glider's buoyancy, producing brief periods of noise ( 15 s). Detection of whistles was impossible during these times; however, because these periods of noise were brief, we did not account for these periods in the quantification of detection rates. In addition, electronic and wave noises were produced while the glider was at the surface during satellite communication periods (10-15 min every $1-2 \mathrm{~h}$ ). Whistles were frequently detected during these times, suggesting little to no reduction in detection capabilities. Whistles were detected at all depths, and there appeared to be no pattern in detections with glider depth.

In 2014, we observed at least one instance where the same animals were recorded on both gliders. We based this assertion on the presence of the same stereotyped whistle contour recorded by both gliders $(\sim 10 \mathrm{~km}$ apart) at approximately the same time (30$40 \mathrm{~s}$ apart). To eliminate the possibility of detecting the same calls twice, we chose to use we04 data and include we10 data only on days when no detections occurred on we04. We did not use any we10 data in spatial analyses.

We observed 2 general classes of whistles throughout all deployments: broken contours containing high numbers of steps with large frequency jumps, and smooth, sinusoidal whistles. Based on visual comparisons between glider-recorded whistles and whistles from Massachusetts Bay species, we believe that broken whistles were produced by Atlantic white-sided dolphins and that smooth whistles were produced by common dolphins (Steiner 1980, 1981, Petrella 2009, Petrella et al. 2012, S. Parks unpubl. data, Northeast Fisheries Science Center unpubl. data). While 2 general whistle classes were evident, we did not attempt to classify detections to species based on visual inspection of recordings because (1) whistles were poor quality in many cases and class could not be determined and (2) it was not always obvious whether all whistles in a recording could be classified as 'broken' or 'smooth.' A classifier for acoustic identification of delphinids is available for the Northwest Atlantic Ocean and includes common dolphins, but not Atlantic white-sided dolphins (Oswald 2013). Future work should focus on obtaining recordings and baseline whistle parameter data for Atlantic white-sided dolphins and acoustic classification of Gulf of Maine species.

\subsection{Spatial occurrence}

Detections occurred throughout the survey area in all deployments, but clustered in broad, different areas between years (Fig. 2). During December 2014, more detections occurred in the eastern part of the survey area. During the period of November 2015 to February 2016, most detections occurred in the southern part of the survey area. Based on 4 quadrat counts of all glider detections combined, the southeastern quadrat contained the highest percentage $(46 \%)$ of all detections (Fig. 2). The average number of detections per kilometer inside the sanctuary (3.0) was more than double that outside the sanctuary (1.4). We did not normalize quadrat counts by track length because quadrats were designed to include roughly the same amount of glider track.

\subsection{Environmental models}

Detections on all gliders exhibited significant spatial autocorrelation. To account for non-independence of data, we averaged environmental variables over bin sizes of $7.5 \mathrm{~km}$ (we04-2014), $15.6 \mathrm{~km}$ (we042015), and $16.8 \mathrm{~km}$ (we10-2015); these distances correspond to those where autocorrelation is 0 . For models combining all gliders, we used a bin size of $15 \mathrm{~km}$, the smallest common distance among all gliders where autocorrelation was not significantly different from 0 . We did not include glider we03 in any envi- 
ronmental models here due to the low number of detections; however, inclusion of we03 data did not change model results in preliminary analysis.

In 2014, detections showed a significant positive association with salinity (median $=33$ PSU, range $=$ 32.4-33.2 PSU, logistic regression, $p<0.01$ ) and depth (median $=59.7 \mathrm{~m}$, range $=31.9-87.9 \mathrm{~m}$, logistic regression, $\mathrm{p}<0.01$ ) and a significant negative association with distance to Stellwagen Bank, reflecting that animals were closer to the Bank (median = $12.8 \mathrm{~km}$, range $=0.2-25.0 \mathrm{~km}$, logistic regression, $\mathrm{p}<$ 0.01; Figs. 2 \& 3). In 2015, detections showed no statistically significant associations with any environmental variables for glider we04. We did not test associations for we10 because all but 2 distance bins had detections. Models combining all gliders showed a significant, negative relationship between detections and distance to the Bank (logistic regression, $\mathrm{p}<0.01$; Table 2, Figs. 2 \& 3). GAMs confirmed linear relationships for significant associations.

\subsection{Temporal occurrence}

Most 1 min recordings (91\%) had no delphinid detections (Table 1). However, 93 of 128 (73\%) deployment days had detections (Table 1). In 2014, detections occurred on 21 of 22 deployment days. Daily detection rates were typically higher when animals were present over multiple consecutive days (Fig. 4). Highest numbers of detections occurred on 6 and 15 December, with over 22 and $40 \%$ of recordings containing detections, respectively (Fig. 4). In 2015, detections occurred on 70 of 106 deployment days (Table 1). We observed detections on 18 of 29 deployment days in November 2015, 28 of 31 deployment days in December 2015, 14 of 16 deployment days in January 2016, and 10 of 29 deployment days in February 2016 (Table 1). Few detections occurred in

Table 2. Single variable models for all gliders combined (except we03); $\mathrm{n}=101$ transect segments $(15 \mathrm{~km})$. Only significant models are shown. Drop in deviance values compare each model to the null model, and p-values are for drop in deviance values. Lower values of Akaike's information criterion (AIC) represent better models. Model coefficients are reported for continuous variables

\begin{tabular}{|lcccc|}
\hline Model & $\begin{array}{c}\text { Model } \\
\text { coefficient }\end{array}$ & $\begin{array}{c}\text { Drop in deviance } \\
\text { (compared to null) }\end{array}$ & p & AIC \\
\hline $\begin{array}{l}\text { Distance to } \\
\text { Bank + Glider }\end{array}$ & -0.18 & 16.6 & $<0.001$ & 86.06 \\
Glider & - & 6.6 & $<0.05$ & 94.07 \\
\hline
\end{tabular}

early November, but detections increased in midand late November. The greatest numbers of detections occurred in late December through mid-January, with up to $89 \%$ of 1 min files containing detections (Fig. 4). The percentage of days with detections was similar in December across the 2 years, although the number of detections was higher in 2015. The number of deployment days with detections and the number of detections per day dramatically decreased in February (Figs. 2 \& 4).

We observed 4 periods during which dense numbers of continuous detections occurred, spanning 4$9 \mathrm{~d}$ and separated by about $3 \mathrm{wk}$ in 2015-2016 (midNovember to mid-January). The number of whistles in each recording during these periods was typically higher than in other periods across all years (Fig. 5). These periods correspond with days that gliders were in the southern part of the survey area (Figs. 2 $\& 4$ ). Coincidentally, we recorded the same unique, stereotyped whistle during the 3 densest periods of detections in early and mid-December and January (Figs. 4 \& 6). We also observed a different, stereotyped whistle, recorded in December 2014 and again in January 2016 (Fig. 6). We believe these are signature whistles (Caldwell \& Caldwell 1965), individually distinctive whistle types produced by a single animal that are used for individual recognition and maintaining group cohesion (Janik \& Sayigh 2013). Signature whistles are stereotyped, often repeated in bouts and remain stable over many years (Sayigh et al. 1990, Janik \& Sayigh 2013, Janik et al. 2013). The repeated occurrence (in occasional bouts and over weeks/years) of unique and distinctive contours suggests that we recorded signature whistles. Repeated, stereotyped whistles have been observed and suggested as signature whistles for Atlantic white-sided dolphins and common dolphins (Caldwell \& Caldwell 1968, Steiner 1980, 1981, Fearey et al. 2019)

We detected delphinids during all hours of the day, but detections showed a clear diel trend for all gliders except we03-2015 (Fig. 7). For all gliders combined, detections were lowest around midday, peaked at 21:00 h, decreased around midnight, and showed an equivalent peak around 03:00 h local time (Fig. 7). Similar trends but additional peaks in detections per hour were observed for each individual glider (Fig. 7). The odds of whistles being present were 1.6 times greater at night (logistic regression, $p=0.033$ ). The magnitude of hourly detection rates for individual deployments mirrored fluctuations in number of detections per day, with greatest detection rates for we10-2015 and lowest for we03-2015 (Fig. 7). Detections showed no significant associations with tidal 

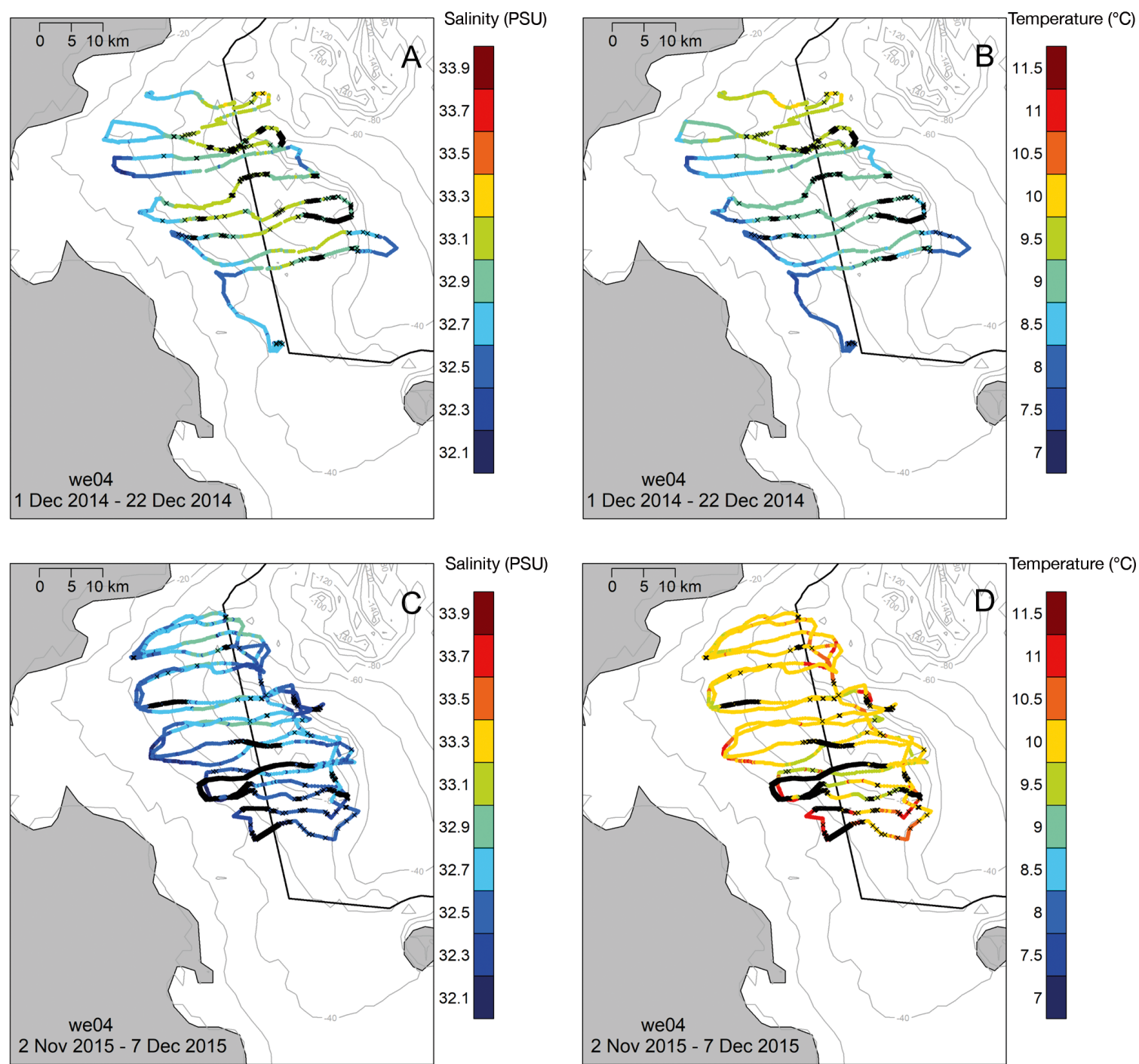

Salinity (PSU)

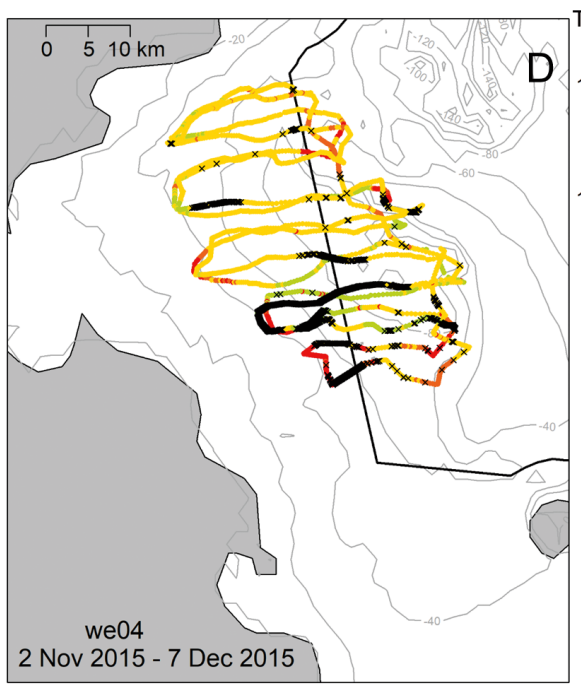

Temperature $\left({ }^{\circ} \mathrm{C}\right)$

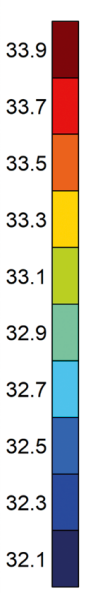

Salinity (PSU)
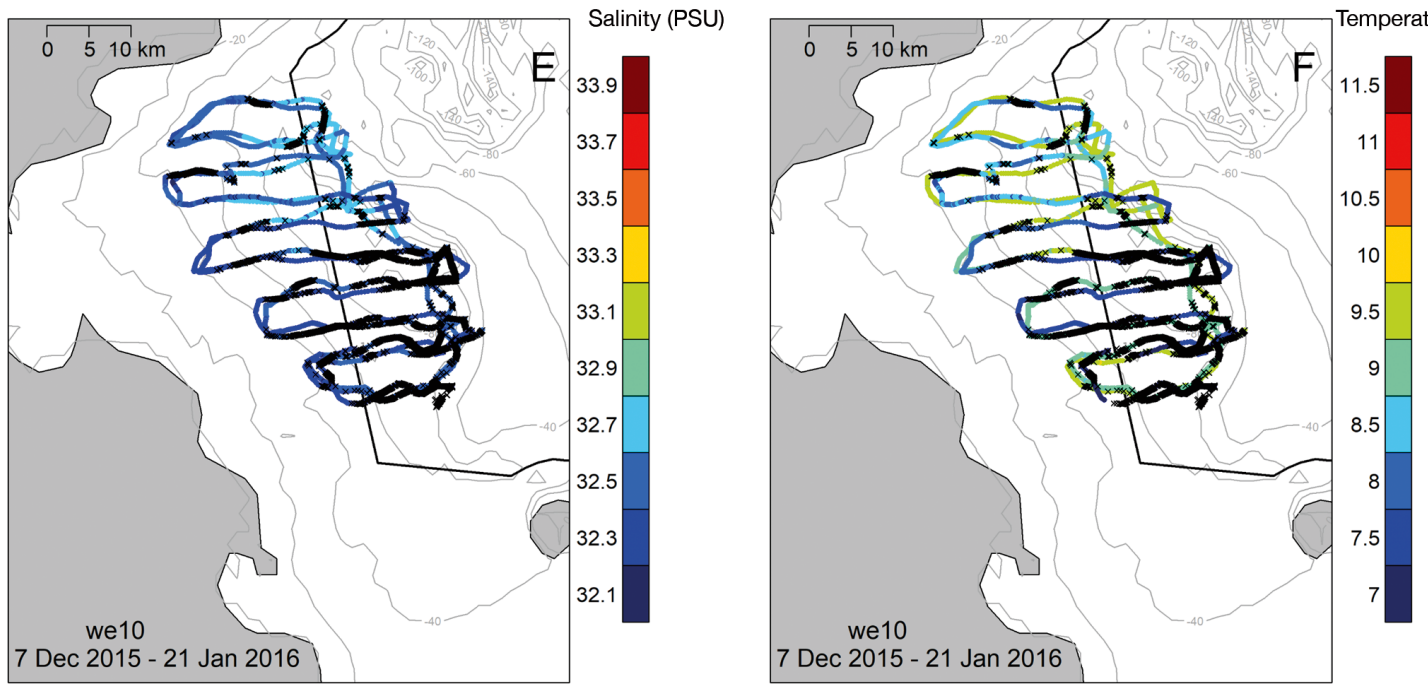

Fig. 3. Near-bottom salinity and temperature data for glider deployments; 2014: $(A, B)$ we04; 2015: (C,D) we04, (E,F) we10. Data were down-sampled to 1 sample $\mathrm{min}^{-1}$ before removing erroneous sensor values. Black $\times$ 's represent detection locations 


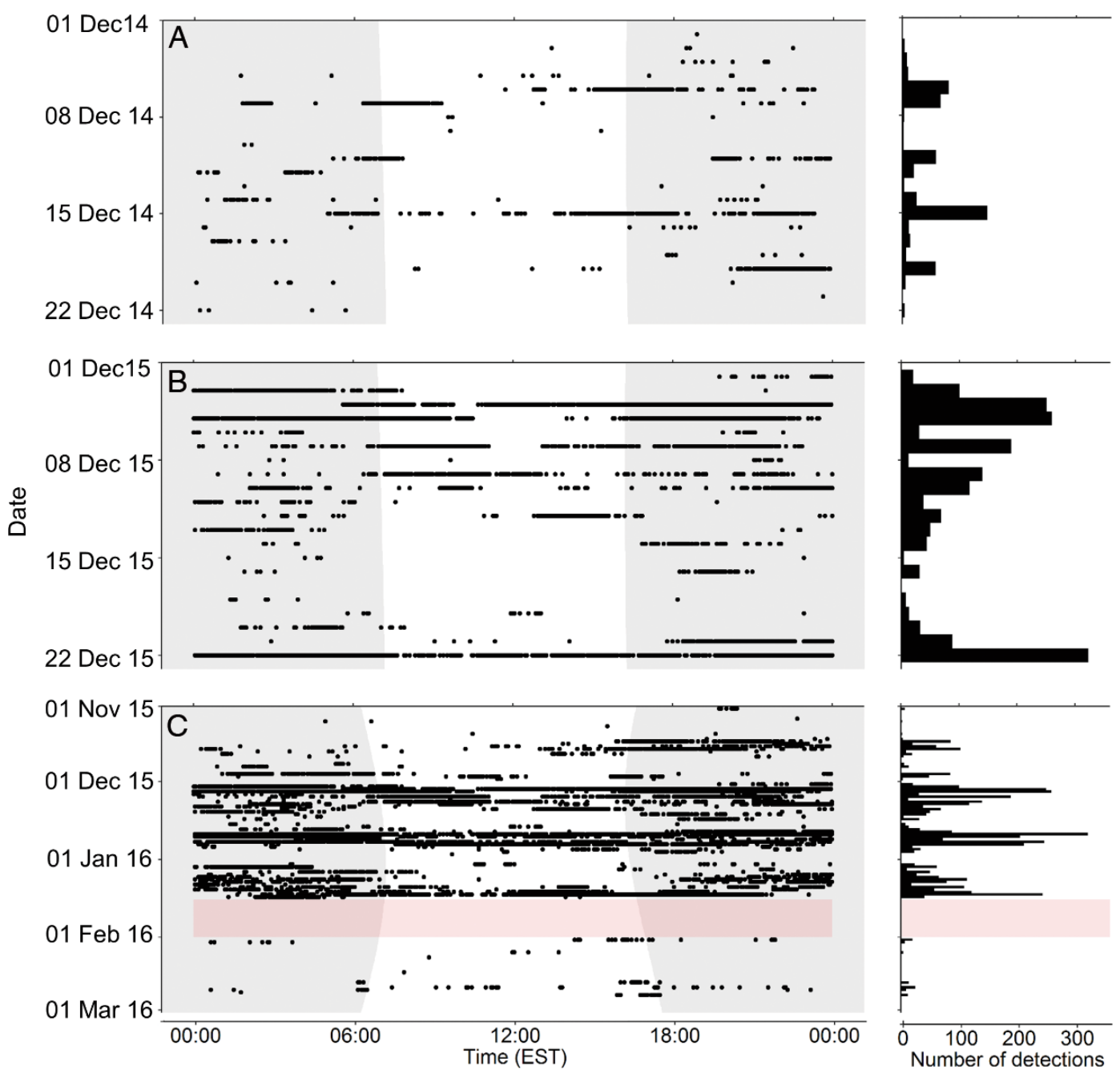

Fig. 4. Detections per hour and per day for all glider deployments. Gray shading represents nighttime hours (sunset to sunrise). The pink box shows a period of no monitoring. The maximum number of detections per day is 360. (A) December 2014 deployment including we04 and we10 data for days when no detections occurred on we04 and (B) the same period in December 2015 for comparison between years. (C) All 2015-2016 deployments

(Kruskal-Wallis, $\mathrm{p}=0.69$ ) or lunar phases (KruskalWallis, $\mathrm{p}=0.33$ ).

\section{DISCUSSION}

We observed a frequent winter presence of delphinids in Massachusetts Bay in 2014 and 20152016. Animals were present on $73 \%$ of deployment days, far more than expected based on opportunistic sighting rates from April to October (Silva 2018, T. L. Silva pers. obs.). Daily delphinid presence was consistent across years, suggesting that delphinid use of the area was common and that the Stellwagen Bank area is likely an important habitat. However, we documented substantial variability in delphinid occur- rence that was only partially explained by environmental conditions.

One challenge of using mobile platforms to study highly mobile species is the difficulty in determining whether variation in detection rates results from differences in space or time. Consecutive glider deployments with multiple surveys from November 2015 to February 2016 revealed that detections increased each time gliders neared southern Stellwagen Basin, indicating that elevated detections represent true spatial differences and preferred habitat in 20152016. Due to lack of consecutive surveys in 2014, differences between space and time remain unresolvable. However, the observation that each individual glider except one (we04-2015) had the most detections in the southeast quadrat provides increased confi- 


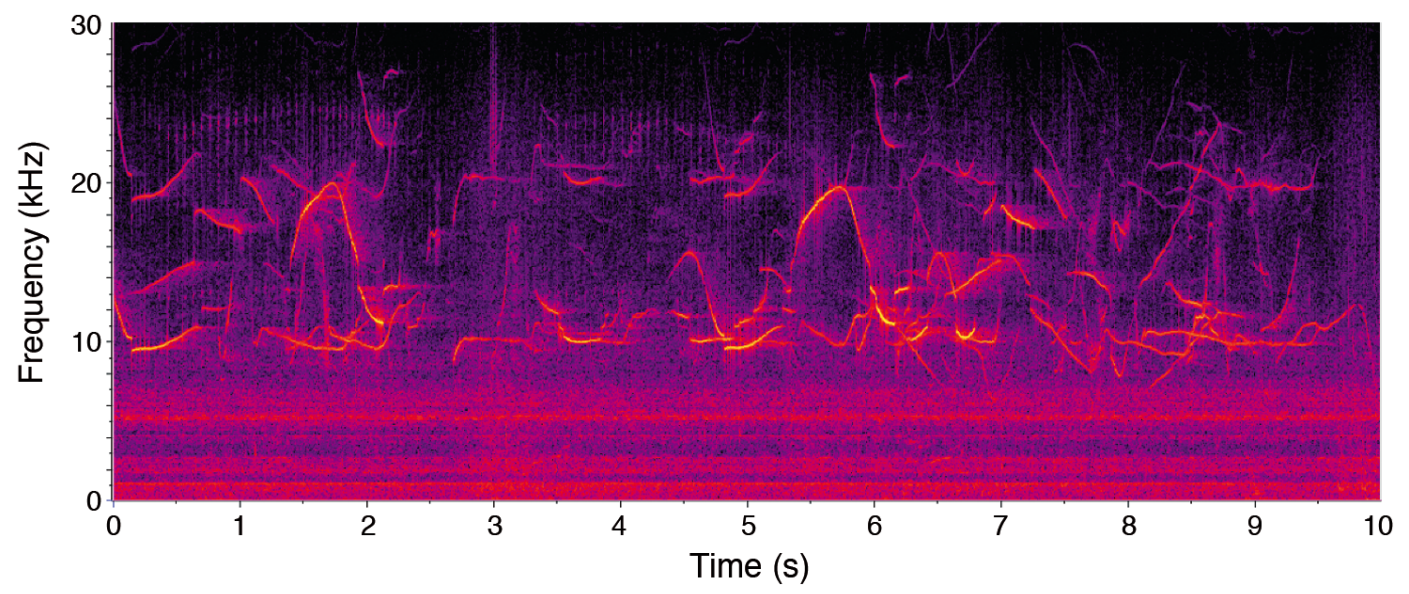

Fig. 5. Example spectrogram showing many overlapping whistles and high call rates often recorded during periods of many detections in southern Stellwagen Basin. This example is from 22 December 2015

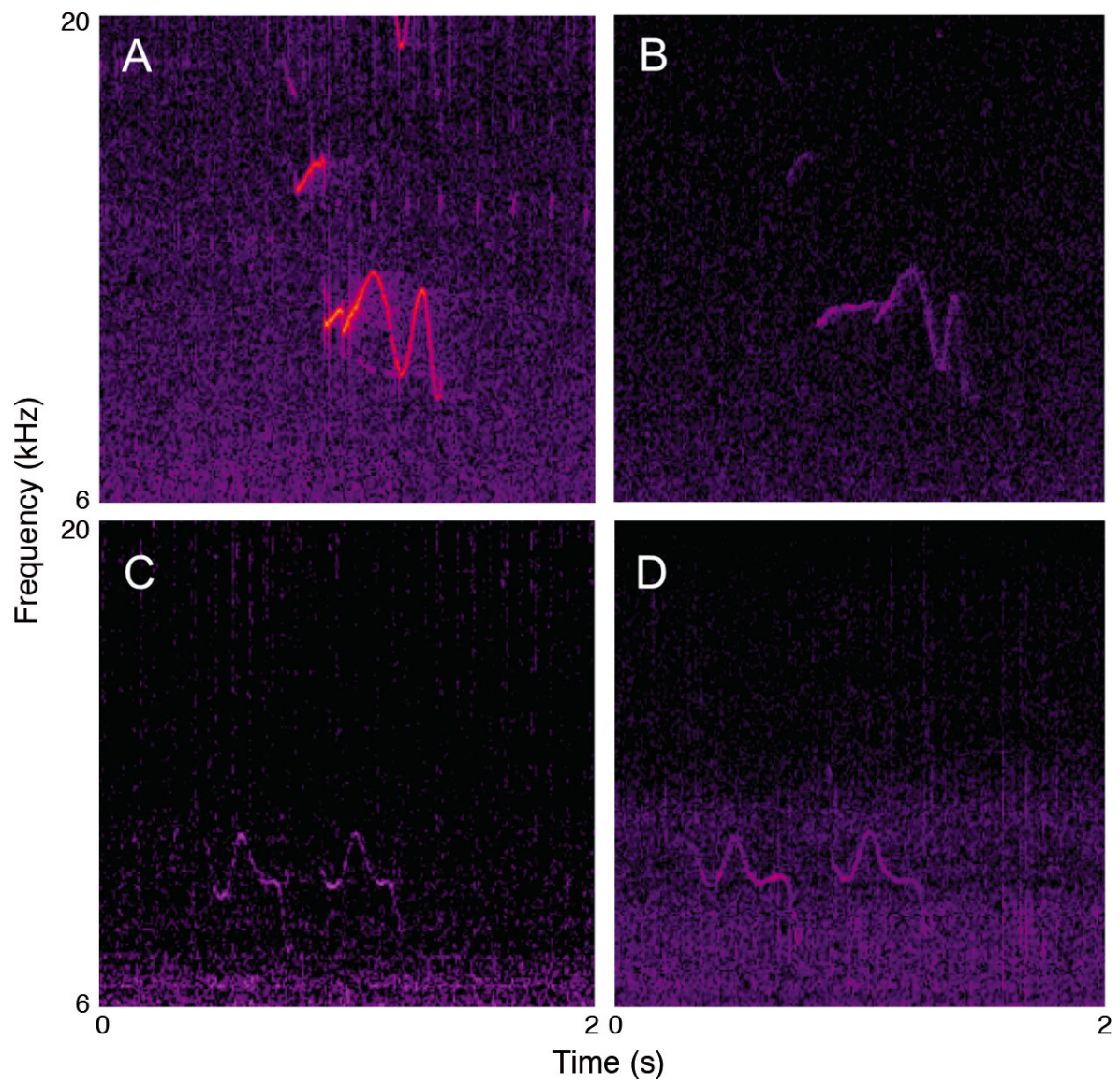

Fig. 6. Spectrograms of unique, stereotyped, repeated whistles. Whistles were documented multiple times $(\mathrm{A}, \mathrm{B})$ in consecutive winter seasons or (C,D) within a season. (A) 12 December 2014, (B) 16 January 2016, (C) 22 December 2015, (D) 15 January 2016

dence that concentrated detections in eastern Stellwagen Basin in 2014 likely reflect spatial preferences. When combining all gliders, we found more detections inside the sanctuary, although considerable numbers of detections occurred outside. These results show that the current sanctuary boundaries aid in capturing some important delphinid habitat, but that delphinids also use areas that lack federal protection. It is important to note that reported detection locations represent glider positions and not true animal loca- 

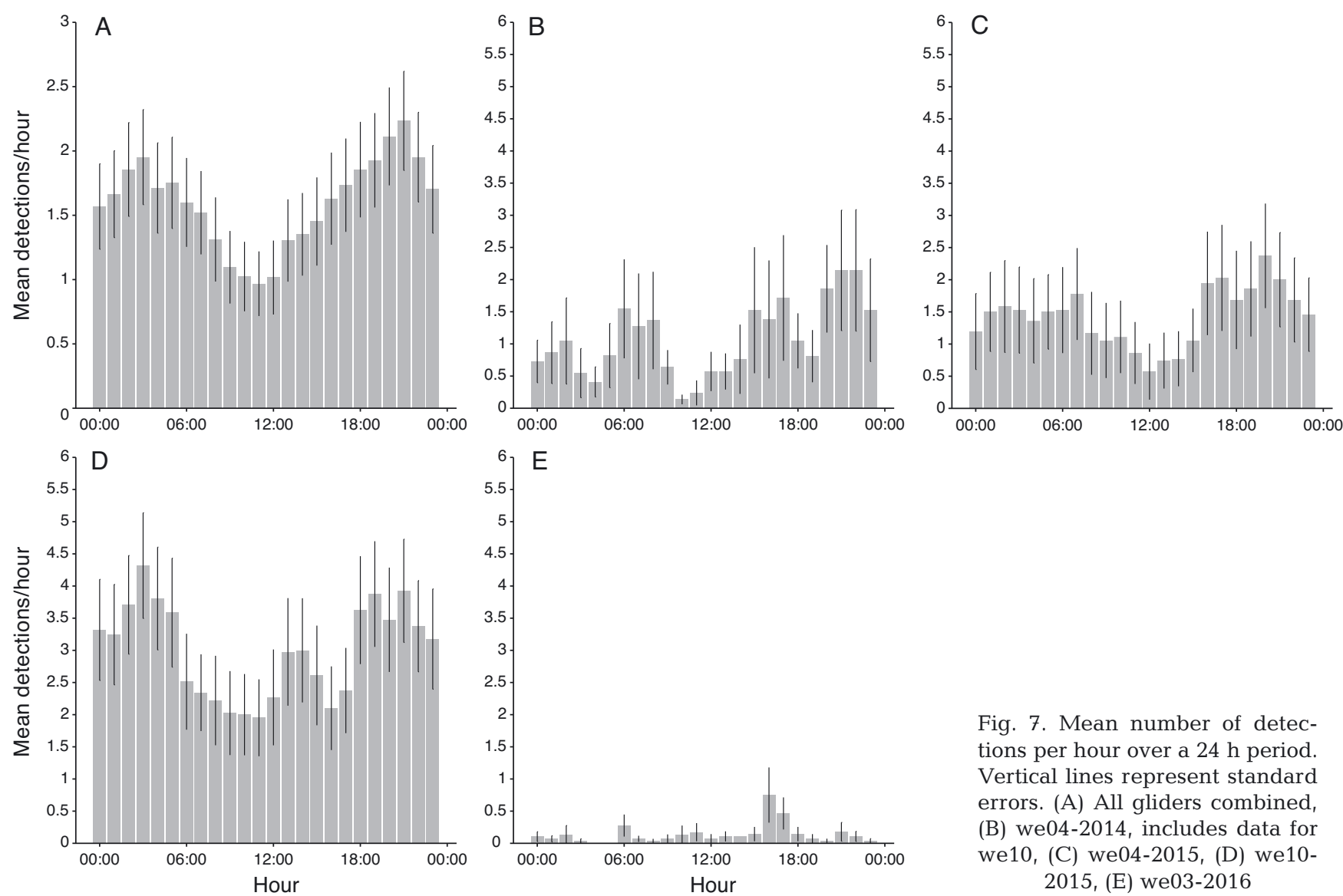

Fig. 7. Mean number of detections per hour over a $24 \mathrm{~h}$ period. Vertical lines represent standard errors. (A) All gliders combined, (B) we04-2014, includes data for we10, (C) we04-2015, (D) we102015, (E) we03-2016

tions. Estimating true animal locations requires information on the detection ranges of delphinid whistles in the study area, which are unknown. However, recordings from concurrently deployed gliders in 2014 suggest that detection ranges could vary from 2 to $10 \mathrm{~km}$. A detection range of $10 \mathrm{~km}$ would allow us to resolve spatial distributions of delphinids at scales $>10 \mathrm{~km}$, which is much smaller than the study area and provides valuable information on spatial distribution without knowing exact animal locations.

Marine mammal distributions are typically correlated with environmental variables that directly influence prey abundance and availability (Hastie et al. 2004, Redfern et al. 2006, Palacios et al. 2013). Our ability to explain spatial distributions of marine mammals through habitat modeling depends on our ability to measure environmental conditions and selection of environmental variables that are relevant in particular habitats for individual species (Palacios et al. 2013). Depth (Baird et al. 2013, Silva et al. 2019), temperature (Selzer \& Payne 1988, Hastie et al. 2005, do Amaral et al. 2015), and salinity (Selzer \& Payne 1988, Doksæter et al. 2008, Hornsby et al. 2017) influence delphinid distributions in Hawaii and in the northwest and southwest Atlantic Ocean; however, those environmental variables may not be important in structuring the availability, abundance, or distributions of prey or delphinids in our study area over any spatial scale. Only distance to Stellwagen Bank was significantly associated with detections across all years. Stellwagen Bank and Stellwagen Basin are known habitat for many fish species (Auster et al. 2001). Increased whistle detections closer to Stellwagen Bank, as well as the presence of echolocation clicks and some presumed foraging buzzes on our glider recordings, suggest that the Stellwagen Bank area may be a foraging ground for delphinids. Acoustic detections of Atlantic cod were concentrated in northern Stellwagen Basin (Zemeckis et al. 2019) where few delphinid detections were recorded, suggesting that delphinids were not targeting this species. Several fish species, including silver hake and haddock, move into deeper waters in the Gulf of Maine in winter and are documented prey for Atlantic white-sided dolphins (Craddock et al. 2009) and the closely related white-beaked dolphin Lagenorhynchus albirostris (Canning et al. 2008). These fish species could over-winter in Stellwagen Basin and attract delphinids. Winter flounder also prefer muddy habitats like those found in Stellwagen Basin (Morse 
et al. 1999, Pereira et al. 1999, Brodziak 2005, Craddock et al. 2009) and could be prey for delphinids.

Additional data on what influences distributions of fish species in Massachusetts Bay and prey preferences of delphinids in the Stellwagen Bank area may help further define important variables for habitat models. Prey switching by delphinids or shifts in prey distribution may explain inter-annual differences in spatial distributions of delphinids. Fish distributions in Stellwagen Bank National Marine Sanctuary show associations with seafloor habitat and sediment type (Auster et al. 2001) and may also be related to zooplankton abundance and diversity (Reed et al. 2018). Copepod density and diversity were correlated with sighting rates of common dolphins and striped dolphins Stenella coeruleoalba (Griffin 1997). Delphinid occurrence is often associated with steep sea-floor slopes (Doksæter et al. 2008, Silva et al. 2019) and high sea-floor relief (Selzer \& Payne 1988, Gowans \& Whitehead 1995, Doksæter et al. 2008). Chlorophyll concentration (Giannoulaki et al. 2017), oceanic fronts (Bailey \& Thompson 2010), and probability of forage fish presence (Giannoulaki et al. 2017) also influence delphinid distributions; future work in Massachusetts Bay could examine these variables.

Several additional factors may have contributed to our inability to explain spatial distributions of detections, including scale of analyses, lack of statistical power, and species differences. First, associations between environmental conditions and detections may occur at spatial scales that we were unable to examine. While our in situ environmental sampling was capable of capturing local (hundreds of meters to tens of kilometers) variation that likely drives prey distributions (Garrison et al. 2002, Methratta \& Link 2006, Reed et al. (2019), this variability is probably lost due to the averaging of environmental variables over large bin sizes needed to account for autocorrelation in detections. Delphinid detections and distributions may be associated with additional static or dynamic environmental covariates, but these relationships were not detectable at the analysis scale used for most deployments. The significant, positive association between detections, salinity, and depth in 2014 may have been identifiable due to smaller bin sizes used in the analysis of this deployment.

Autocorrelation in acoustic data partially relates to detection ranges of signals of interest. If detection ranges of delphinid whistles exceed the scale of analysis or more importantly, local scale environmental variation, relationships between detections and environmental conditions may be obscured. Bin sizes used here were mostly larger than the $2-10 \mathrm{~km}$ detection range suggested by concurrent glider recordings, and therefore, fine-scale habitat use was not resolvable. One alternative approach is to focus on echolocation clicks, which we observed on recordings from all deployments. While delphinids use clicks in several circumstances, clicks and especially buzzes could suggest foraging behavior. Clicks likely have a smaller detection range than whistles due to their higher frequency content and increased energy absorption (Urick 1983). Thus the occurrence of echolocation clicks may reflect stronger, finer-scale associations between delphinids and environmental variables. Analysis of echolocation and potential foraging behavior was outside the scope of this study; however, future analysis of these signals may reduce autocorrelation in the data, allow for smaller analysis scales, and more clearly identify relationships.

Second, the statistical test used here may lack sufficient power to identify associations between environmental conditions and detections. Additional glider surveys would increase sample sizes and statistical power, enabling identification of more subtle associations between environmental factors and detections.

Lastly, variation in occurrence may also reflect differences between species. Atlantic white-sided dolphins and common dolphins overlap in many areas, but have different geographic ranges and prefer different habitats. Atlantic white-sided dolphins prefer colder, fresher water, while common dolphins prefer warmer, saltier water (Cetacean and Turtle Assessment Program 1982, Selzer \& Payne 1988, Gowans \& Whitehead 1995, Griffin 1997, Doksæeter et al. 2008). Associations between detections and oceanographic conditions may be more obvious when examining species separately.

Observed monthly and annual variation in dolphin occurrence corroborates results from vessel surveys that show similar sighting frequencies for November through January and a decrease in February (Wiley et al. 2003, NOAA ONMS 2010). These data suggest that delphinids move into the Stellwagen Bank area in late November through mid-January, leave the area in February, and return in high numbers in AprilMay (Silva 2018, Silva et al. 2019). Additional acoustic monitoring in March, September, and October where opportunistic data collection from whale watching vessels is limited or non-existent due to decreased effort is needed to better understand monthly variation throughout the year.

In December of both years, we detected delphinids on over $90 \%$ of deployment days, although the total number of daily detections and periods of many continuous detections were greater in 2015 (Fig. 4). Sev- 
eral factors influence whistle rates in delphinids (Quick \& Janik 2008, Esch et al. 2009). Here, interannual variation in the number of detections may indicate that more animals used the area in 2015. Alternatively, variation in detection rates may reflect changes in behavior. Increased detection rates may indicate foraging, particularly at night as animals increase acoustic communication as light and visual cues fade (Goold 2000, Acevedo-Gutiérrez \& Stienessen 2004). We detected animals significantly more often at night (Figs. 4 \& 6), which we assume represents increased vocalization rates as opposed to increased nighttime presence. No information exists on foraging behavior or acoustic activity in Atlantic white-sided dolphins, but common dolphins are known to forage at night (Henderson et al. 2012, Simonis et al. 2017), and some populations increase whistle activity when foraging (Petrella et al. 2012). Goold (2000) observed higher vocalization rates at night in common dolphins around the British Isles, and patterns in acoustic contact were similar to results here; peak acoustic contact occurred in the early morning and late evening, often encompassing 03:00 and 21:00 h, and lowest acoustic contact occurred around mid-day. Months or years with lower numbers of detections may reflect decreased movement into the Stellwagen Bank area, shorter occupancy, or fewer animals, potentially driven by lower prey availability and fewer foraging opportunities.

Diel patterns have important implications for habitat-use studies. Continuous (day and night) acoustic monitoring provides valuable information on nighttime occurrence and potentially behavior that is not observable with visual surveys. However, if diel patterns exist, acoustic monitoring alone may underestimate daytime occurrence. These findings highlight the benefits of combined visual and acoustic surveys to study occurrence.

We noted the presence of 2 unique, stereotyped whistle types, each recorded more than once, which we presume to be individual signature whistles (Caldwell \& Caldwell 1965). One whistle type was recorded in consecutive winter seasons (December 2014 and January 2016), providing evidence of annual habitat use by the same individual. The second whistle was recorded on at least 10 days over a 41 d period spanning December 2015 to January 2016. All instances were when the glider was in southern Stellwagen Basin, suggesting that either a group of animals visited southern Stellwagen Basin multiple times over several weeks, or this group stayed in southern Stellwagen Basin for at least $41 \mathrm{~d}$. We believe the latter to be true, as the chances of an animal or group of animals moving into the same area at a consistent time interval and being in detection range of the glider each time seems low.

Based on opportunistic data collected from whale watching and research vessels from April to October, Weinrich et al. (2001) proposed that Atlantic whitesided dolphins were non-resident and transiently used the Stellwagen Bank area as part of a much larger home range. This hypothesis was based on 3 lines of evidence: (1) traveling was the predominant behavior, (2) only 1 individual was re-sighted on Stellwagen Bank in consecutive years over a $13 \mathrm{yr}$ period, and (3) no individuals were re-sighted within the same area in the same year. We provide evidence of delphinid annual site fidelity and the first documentation of habitat use by a single group of animals throughout a winter season.

These observations add valuable information to our understanding of delphinid habitat use in Massachusetts Bay and alter current thinking shaped by anecdotal information and visual sightings. Based on an admittedly small dataset, we hypothesize that Massachusetts Bay and the Stellwagen Bank area are important foraging grounds for delphinids and that they visit this area often during winter in search of prey. Animals generally occur closer to Stellwagen Bank, but we propose that finer-scale spatial distributions and length of occupancy depend on fish abundance, availability, and distribution.

This work represents the first exploration of delphinid habitat use in Massachusetts Bay and demonstrates the value and advantages of passive acoustic monitoring in studying the occurrence and behavior of highly mobile, cryptic species. Delphinids use Massachusetts Bay frequently and consistently during most winter months, suggesting that they may play a significant role in shaping the Massachusetts Bay ecosystem. This work suggests the need for complementary summer (or year-round) glider-based acoustic surveys to appropriately identify seasonal shifts in delphinid occurrence. Additional avenues for future work are acoustic species identification, deriving additional environmental variables and echolocation rates to describe habitat use on finer scales, testing hypotheses about prey-driven distributions by measuring prey in situ using gliders (Baumgartner \& Fratantoni 2008, Guihen et al. 2014), and examining overlap between delphinids and year-round human activity in Massachusetts Bay.

Acknowledgements. We gratefully acknowledge the NOAA Northeast Fisheries Science Center, Stellwagen Bank National Marine Sanctuary, The Nature Conservancy, Massachusetts Division of Marine Fisheries, and the University of Massachusetts Dartmouth for their collaboration and sup- 
port for this project. We thank Susan Parks, Julie Oswald, Sofie Van Parijs, and Danielle Cholewiak for helpful discussions and sharing acoustic recordings for species comparisons. We are grateful to Ben Hodges for critical assistance with preparing, deploying, and recovering gliders. Thanks to Michael Thompson for assistance with spatial analysis and Dave Wiley for support and insights into the Stellwagen Bank ecosystem. The WHOI Marine Mammal Center provided additional funding for this work. Funding support for T.L.S. was provided by the NOAA Dr. Nancy Foster Scholarship. Finally, we thank the 3 anonymous reviewers for their comments and suggestions that improved this manuscript.

\section{LITERATURE CITED}

Acevedo-Gutiérrez A, Stienessen SC (2004) Bottlenose dolphins (Tursiops truncatus) increase number of whistles when feeding. Aquat Mammal 30:357-362

Asaro MJ (2012) Geospatial analysis of management areas implemented for protection of the North Atlantic right whale along the northern Atlantic coast of the United States. Mar Policy 36:915-921

Auster PJ, Joy K, Valentine PC (2001) Fish species and community distributions as proxies for seafloor habitat distributions: the Stellwagen Bank National Marine Sanctuary example (Northwest Atlantic, Gulf of Maine). Environ Biol Fishes 60:331-346

Bailey H, Thompson P (2010) Effect of oceanographic features on fine-scale foraging movements of bottlenose dolphins. Mar Ecol Prog Ser 418:223-233

* Baird RW, Webster DL, Aschettino JM, Schorr GS, McSweeney DJ (2013) Odontocete cetaceans around the main Hawaiian Islands: habitat use and relative abundance from small-boat sighting surveys. Aquat Mamm 39:253-269

Baumgartner MF, Fratantoni DM (2008) Diel periodicity in both sei whale vocalization rates and the vertical migration of their copepod prey observed from ocean gliders. Limnol Oceanogr 53:2197-2209

* Baumgartner MF, Cole TVN, Clapham PJ, Mate BR (2003) North Atlantic right whale habitat in the lower Bay of Fundy and on the SW Scotian Shelf during 1999-2001. Mar Ecol Prog Ser 264:137-154

Baumgartner MF, Fratantoni DM, Hurst TP, Brown MW, Cole TVN, Van Parijs SM, Johnson M (2013) Real-time reporting of baleen whale passive acoustic detections from ocean gliders. J Acoust Soc Am 134:1814-1823

Baumgartner MF, Stafford KM, Winsor P, Statscewich H, Fratantoni DM (2014) Glider-based passive acoustic monitoring in the arctic. Mar Technol Soc J 48:40-51

Bjornstad ON (2016) ncf: Spatial Nonparametric Covariance Functions. R package version 1.1-7. http://cran.nexr.com/ web/packages/ncf/index.html

Bowen WD (1997) Role of marine mammals in aquatic ecosystems. Mar Ecol Prog Ser 158:267-274

* Bradford AL, Forney KA, Oleson EM, Barlow J (2017) Abundance estimates of cetaceans from a line-transect survey within the US Hawaiian Islands Exclusive Economic Zone. Fish Bull 115:129-142

* Breed GA, Matthews CJD, Marcoux M, Higdon JW and others (2017) Sustained disruption of narwhal habitat use and behavior in the presence of Arctic killer whales. Proc Natl Acad Sci USA 114:2628-2633

Brodziak J (2005) Essential fish habitat source document: haddock, Melanogrammus aeglefinus, life history and habitat characteristics, $2^{\text {nd }}$ edn. NOAA Tech Memo NMFSNE-196. National Oceanic and Atmospheric Administration, Woods Hole, MA

Bumpus DF (1974) Review of the physical oceanography of Massachusetts Bay. Tech Rep 74-8. Woods Hole Oceanographic Institution, Woods Hole, MA

* Caldwell MC, Caldwell DK (1965) Individualized whistle contours in bottle-nosed dolphins (Tursiops truncatus). Nature 207:434-435

* Caldwell MC, Caldwell DK (1968) Vocalization of naive captive dolphins in small groups. Science 159: 1121-1123

Canning SJ, Santos MB, Reid RJ, Evans PG, Sabin RC, Bailey N, Pierce GJ (2008) Seasonal distribution of whitebeaked dolphins (Lagenorhynchus albirostris) in UK waters with new information on diet and habitat use. J Mar Biol Assoc UK 88:1159-1166

Cetacean and Turtle Assessment Program (1982) A characterization of marine mammals and turtles in the mid- and north-Atlantic areas of the U.S. outer continental shelf. Final Report No. AA551-CT8-48 of Cetacean and Turtle Assessment Program (CETAP) to the Bureau of Land Management, U.S. Department of the Interior, Washington, DC

Charif R, Waack A, Strickman L (2010) Raven Pro 1.4 user's manual. Cornell Laboratory of Ornithology, Ithaca, NY

Craddock JE, Polloni PT, Hayward B, Wenzel F (2009) Food habits of Atlantic white-sided dolphins (Lagenorhynchus acutus) off the coast of New England. Fish Bull 107: 384-394

* do Amaral KB, Alvares DJ, Heinzelmann L, Borges-Martins M, Siciliano S, Moreno IB (2015) Ecological niche modeling of Stenella dolphins (Cetartiodactyla: Delphinidae) in the southwestern Atlantic Ocean. J Exp Mar Biol Ecol 472:166-179

ํoksæter L, Olsen E, Nøttestad L, Fernö A (2008) Distribution and feeding ecology of dolphins along the MidAtlantic Ridge between Iceland and the Azores. Deep Sea Res II 55:243-253

* Dormann CF, McPherson JM, Araújo MB, Bivand R and others (2007) Methods to account for spatial autocorrelation in the analysis of species distributional data: a review. Ecography 30:609-628

Esch HC, Sayigh LS, Blum JE, Wells RS (2009) Whistles as potential indicators of stress in bottlenose dolphins (Tursiops truncatus). J Mammal 90:638-650

* Estes JA, Tinker MT, Williams TM, Doak DF (1998) Killer whale predation on sea otters linking oceanic and nearshore systems. Science 282:473-476

KEstes JA, Heithaus M, McCauley DJ, Rasher DB, Worm B (2016) Megafaunal impacts on structure and function of ocean ecosystems. Annu Rev Environ Resour 41:83-116

* Fearey J, Elwen SH, James BS, Gridley T (2019) Identification of potential signature whistles from free-ranging common dolphins (Delphinus delphis) in South Africa. Anim Cogn 22:777-789

Garrison LP, Michaels W, Link JS, Fogarty MJ (2002) Spatial distribution and overlap between ichthyoplankton and pelagic fish and squids on the southern flank of Georges Bank. Fish Oceanogr 11:267-285

Geyer WR, Gardner GG, Brown WS, Irish J, Butman B, Loder T, Signell RP (1992) Physical oceanographic investigation of Massachusetts and Cape Cod Bays. Tech Rep MBP-92-03. Massachusetts Bays Program. USEPA Region I/Massachusetts Coastal Zone Office, Boston, MA 
Giannoulaki M, Markoglou E, Valavanis VD, Alexiadou $\mathrm{P}_{1}$ Cucknell A, Frantzis A (2017) Linking small pelagic fish and cetacean distribution to model suitable habitat for coastal dolphin species, Delphinus delphis and Tursiops truncatus, in the Greek Seas (Eastern Mediterranean). Aquat Conserv 27:436-451

Goold JC (2000) A diel pattern in vocal activity of shortbeaked common dolphins, Delphinus delphis. Mar Mamm Sci 16:240-244

Gowans S, Whitehead H (1995) Distribution and habitat partitioning by small odontocetes in the Gully, a submarine canyon on the Scotian Shelf. Can J Zool 73:1599-1608

Griffin R (1997) Relationships between odontocete distributions and zooplankton community structure along the southern edge of Georges Bank. J Northwest Atl Fish Sci 22:27-36

Guihen D, Fielding S, Murphy EJ, Heywood KJ, Griffiths G (2014) An assessment of the use of ocean gliders to undertake acoustic measurements of zooplankton: the distribution and density of Antarctic krill (Euphausia superba) in the Weddell Sea. Limnol Oceanogr Methods 12:373-389

* Hastie G, Wilson B, Wilson LJ, Parsons KM, Thompson PM (2004) Functional mechanisms underlying cetacean distribution patterns: hotspots for bottlenose dolphins are linked to foraging. Mar Biol 144:397-403

*Hastie GD, Swift RJ, Slesser G, Thompson PM, Turrell WR (2005) Environmental models for predicting oceanic dolphin habitat in the Northeast Atlantic. ICES J Mar Sci 62: 760-770

Hatch L, Clark C, Merrick R, Van Parijs S and others (2008) Characterizing the relative contributions of large vessels to total ocean noise fields: a case study using the Gerry E. Studds Stellwagen Bank National Marine Sanctuary. Environ Manag 42:735-752

Hatch LT, Clark CW, Van Parijs SM, Frankel AS, Ponirakis DW (2012) Quantifying loss of acoustic communication space for right whales in and around a US National Marine Sanctuary. Conserv Biol 26:983-994

*Henderson EE, Hildebrand JA, Smith MH, Falcone EA (2012) The behavioral context of common dolphin (Delphinus sp.) vocalizations. Mar Mamm Sci 28:439-460

Hornsby FE, McDonald TL, Balmer BC, Speakman TR and others (2017) Using salinity to identify common bottlenose dolphin habitat in Barataria Bay, Louisiana, USA. Endang Species Res 33:181-192

Janik VM, Sayigh LS (2013) Communication in bottlenose dolphins: 50 years of signature whistle research. J Comp Physiol A Neuroethol Sens Neural Behav Physiol 199: 479-489

Janik VM, King SL, Sayigh LS, Wells RS (2013) Identifying signature whistles from recordings of groups of unrestrained bottlenose dolphins (Tursiops truncatus). Mar Mamm Sci 29:109-122

* Jiang M, Brown MW, Turner JT, Kenney RD, Mayo CA, Zhang Z, Zhou M (2007) Springtime transport and retention of Calanus finmarchicus in Massachusetts and Cape Cod Bays, USA, and implications for right whale foraging. Mar Ecol Prog Ser 349:183-197

Kellar NM, Speakman TR, Smith CR, Lane SM and others (2017) Low reproductive success rates of common bottlenose dolphins Tursiops truncatus in the northern Gulf of Mexico following the Deepwater Horizon disaster (20102015). Endang Species Res 33:143-158

Kelley D, Richards C (2016) oce: analysis of oceanographic data. R package version 0.9-20. https://github.com/cran/ oce/releases

Kenney RD, Scott GP, Thompson TJ, Winn HE (1997) Estimates of prey consumption and trophic impacts of cetaceans in the USA northeast continental shelf ecosystem. J Northwest Atl Fish Sci 22:155-171

KKiszka JJ, Heithaus MR, Wirsing AJ (2015) Behavioural drivers of the ecological roles and importance of marine mammals. Mar Ecol Prog Ser 523:267-281

K Klinck H, Mellinger DK, Klinck K, Bogue NM and others (2012) Near-real-time acoustic monitoring of beaked whales and other cetaceans using a Seaglider ${ }^{\mathrm{TM}}$. PLOS ONE 7:e36128

Lammers MO, Au WWL (2003) Directionality in the whistles of Hawaiian spinner dolphins (Stenella longirostris): a signal feature to cue direction of movement? Mar Mamm Sci 19:249-264

Kegendre P (1993) Spatial autocorrelation: trouble or new paradigm? Ecology 74:1659-1673

* MacLeod R, MacLeod CD, Learmonth JA, Jepson PD, Reid RJ, Deaville R, Pierce GJ (2007) Mass-dependent predation risk and lethal dolphin-porpoise interactions. Proc R Soc B 274:2587-2593

*Mellinger DK, Stafford KM, Moore SE, Dziak RP, Matsumo $\mathrm{H}$ (2007) An overview of fixed passive acoustic observation methods for cetaceans. Oceanography 20:36-45

* Methratta ET, Link JS (2006) Seasonal variation in groundfish habitat associations in the Gulf of Maine-Georges Bank region. Mar Ecol Prog Ser 326:245-256

* Meynier L, Pusineri C, Spitz J, Santos MB, Pierce GJ, Ridoux $\mathrm{V}$ (2008) Intraspecific dietary variation in the shortbeaked common dolphin Delphinus delphis in the Bay of Biscay: importance of fat fish. Mar Ecol Prog Ser 354: 277-287

Morse WW, Johnson DL, Berrien PL, Wilk SJ (1999) Essential fish habitat source document: silver hake, Merluccius bilinearis, life history and habitat characteristics. NOAA Tech Memo NMFS NE-135. National Fisheries Service, Highlands, NJ

* Mussoline SE, Risch D, Hatch LT, Weinrich MT and others (2012) Seasonal and diel variation in North Atlantic right whale up-calls: implications for management and conservation in the northwestern Atlantic Ocean. Endang Species Res 17:17-26

NOAA OMNS (National Oceanic and Atmospheric Administration Office of National Marine Sanctuaries) (2010) Stellwagen Bank National Marine Sanctuary Final Management Plan and Environmental Assessment. US Department of Commerce, NOAA, Silver Spring, MD

Oswald JN (2013) Development of a classifier for the acoustic identification of delphinid species in the Northwest Atlantic Ocean. Final Report. Prepared for Naval Facilities Engineering Command Atlantic, Norfolk, Virginia, under HDR Environmental, Operations and Construction, Inc. Norfolk, Virginia Contract No. CON0054394-009, Subproject 164744, Task Order 003, Agreement \# 105067. Prepared by Bio-Waves, Inc., Encinitas, CA

Oswald JN, Barlow J, Norris TF (2003) Acoustic identification of nine delphinid species in the eastern tropical Pacific Ocean. Mar Mamm Sci 19:20-37

Oswald JN, Rankin S, Barlow J, Lammers MO (2007) A tool for real-time acoustic species identification of delphinid whistles. J Acoust Soc Am 122:587-595

Overholtz WJ, Link JS (2007) Consumption impacts by marine mammals, fish, and seabirds on the Gulf of Maine- 
Georges Bank Atlantic herring (Clupea harengus) complex during the years 1977-2002. ICES J Mar Sci 64: 83-96

Overholtz WJ, Nicolas JR (1979) Apparent feeding by the fin whale, Balaenoptera physalus, and humpback whale, Megaptera novaeangliae, on the American sand lance, Ammodytes americanus, in the northwest Atlantic. Fish Bull 77:285-287

Palacios DM, Baumgartner MF, Laidre KL, Gregr EJ (2013) Beyond correlation: integrating environmentally and behaviourally mediated processes in models of marine mammal distributions. Endang Species Res 22:191-203

Pante E, Simon-Bouhet B (2013) marmap: a package for importing, plotting and analyzing bathymetric and topographic data in R. PLOS ONE 8:e73051

Pereira JJ, Goldberg R, Ziskowski JJ, Berrian PL, Morse WW, Johnson DL (1999) Essential fish habitat source document: winter flounder, Pseudopleuronectes americanus, life history and habitat characteristics. NOAA Tech Memo NMFS-NE 138. National Fisheries Service, Highlands, NJ

Petrella V (2009) Whistle characteristics of common dolphins (Delphinus sp.) in the Hauraki Gulf, New Zealand. PhD thesis, University of Naples

Petrella V, Martinez E, Anderson MG, Stockin KA (2012) Whistle characteristics of common dolphins (Delphinus sp.) in the Hauraki Gulf, New Zealand. Mar Mamm Sci 28:479-496

Quick NJ, Janik VM (2008) Whistle rates of wild bottlenose dolphins (Tursiops truncatus): influences of group size and behavior. J Comp Psychol 122:305-311

R Core Team (2017) R: a language and environment for statistical computing. R Foundation for Statistical Computing, Vienna

Read AJ, Drinker P, Northridge S (2006) Bycatch of marine mammals in US and global fisheries. Conserv Biol 20: 163-169

Redfern JV, Ferguson MC, Becker EA, Hyrenbach KD and others (2006) Techniques for cetacean-habitat modeling. Mar Ecol Prog Ser 310:271-295

Reed D, Plourde S, Cook A, Pepin P, Casault B, Lehoux C, Johnson C (2018) Response of Scotian Shelf silver hake (Merluccius bilinearis) to environmental variability. Fish Oceanogr 28:256-272

Roman J, McCarthy JJ (2010) The whale pump: Marine mammals enhance primary productivity in a coastal basin. PLOS ONE 5:e13255

Rudnick DL, Davis RE, Eriksen CC, Fratantoni DM, Perry MJ (2004) Underwater gliders for ocean research. Mar Technol Soc J 38:73-84

Sayigh LS, Tyack PL, Wells RS, Scott MD (1990) Signature whistles of free-ranging bottlenose dolphins, Tursiops truncatus: mother-offspring comparisons. Behav Ecol Sociobiol 26:247-260

Selzer LA, Payne PM (1988) The distribution of white sided (Lagenorhynchus acutus) and common dolphins (Delphinus delphis) vs. environmental features of the continental shelf of the northeastern United States. Mar Mamm Sci 4:141-153

Silva TL (2018) Habitat use and bioacoustics of toothed whales in two national marine sanctuaries. PhD dissertation, University of Massachusetts Dartmouth, North Dartmouth, MA
Silva TL, Fay G, Mooney TA, Robbins J and others (2019) Habitat use of toothed whales in a marine protected area based on point process models. Mar Ecol Prog Ser 609: 239-256

Simonis AE, Roch MA, Bailey B, Barlow J and others (2017) Lunar cycles affect common dolphin Delphinus delphis foraging in the Southern California Bight. Mar Ecol Prog Ser 577:221-235

Steiner WW (1980) A comparative study of the pure tonal whistle vocalizations from five western north Atlantic dolphin species. PhD thesis, University of Rhode Island, Kingston, RI

Steiner WW (1981) Species-specific differences in pure tonal whistle vocalizations of five western north Atlantic dolphin species. Behav Ecol Sociobiol 9:241-246

Thorne LH, Foley HJ, Baird RW, Webster DL, Swaim ZT, Read AJ (2017) Movement and foraging behavior of short-finned pilot whales in the Mid-Atlantic Bight: importance of bathymetric features and implications for management. Mar Ecol Prog Ser 584:245-257

Tyack PL, Johnson M, Soto NA, Sturlese A, Madsen PT (2006) Extreme diving of beaked whales. J Exp Biol 209: 4238-4253

Urick RJ (1983) Principles of underwater sound. Peninsula Publishing, Los Altos, CA

* Van der Hoop JM, Moore MJ, Barco SG, Cole TVN and others (2013) Assessment of management to mitigate anthropogenic effects on large whales. Conserv Biol 27:121-133

Van Parijs SM, Clark CW, Sousa-Lima RS, Parks SE, Rankin S, Risch D, Van Opzeeland IC (2009) Management and research applications of real-time and archival passive acoustic sensors over varying temporal and spatial scales. Mar Ecol Prog Ser 395:21-36

Weinrich M, Belt C, Morin D (2001) Behavior and ecology of the Atlantic white-sided dolphin (Lagenorhynchus acutus) in coastal New England waters. Mar Mamm Sci 17:231-248

* Wells RS, Rhinehart HL, Cunningham P, Whaley J, Baran M, Koberna C, Costa DP (1999) Long distance offshore movements of bottlenose dolphins. Mar Mamm Sci 15: 1098-1114

Wiley DN, Early G, Mayo CA, Moore MJ (2001) Rescue and release of mass stranded cetaceans form beaches on Cape Cod, Massachusetts, USA; 1990-1999: a review of some response actions. Aquat Mamm 27:162-171

Wiley DN, Moller JC, Zilinskas KA (2003) The distribution and density of commercial fisheries and baleen whales within the Stellwagen Bank National Marine Sanctuary: July 2001-June 2002. Mar Technol Soc J 37:35-53

Wiley D, Thompson M, Hatch L, Schwehr K, MacDonald C (2013) Marine sanctuaries and marine planning: protecting endangered marine life. Coast Guard J Saf Secur Sea Proc Mar Saf Secur Counc 70:10-15

Williams TM, Estes JA, Doak DF, Springer AM (2004) Killer appetites: assessing the role of predators in ecological communities. Ecology 85:3373-3384

Wood SN (2011) Fast stable restricted maximum likelihood and marginal likelihood estimation of semiparametric generalized linear models. J R Stat Soc B 73:3-36

Z Zemeckis DR, Dean MJ, DeAngelis AI, Van Parijs SM and others (2019) Identifying the distribution of Atlantic cod spawning using multiple fixed and glider-mounted acoustic technologies. ICES J Mar Sci fsz064 doi:10. 1093/icesjms/fsz064

Submitted: February 5, 2019; Accepted: October 30, 2019

Proofs received from author(s): November 16, 2019 